\title{
Management of Facilities and Infrastructure of Physical Education in State Junior High School
}

\section{Jajang1*, Sugeng Purwanto², Fitri Agung Nanda ${ }^{3}$, Novriansyah ${ }^{4}$}

1,2,3,4 Postgraduate Sport Science, Yogyakarta State University, Yogyakarta, Indonesia

\section{A R T I C L E I N F O}

Article history:

Received March 01, 202

Revised March 03, 2021

Accepted April 11, 2021

Available online May 25, 2021

Kata Kunci :

Pendidikan Jasmani, Fasilitas, Infrastruktur, Manajemen

Keywords:

Physical Education, Facilities, Infrastructure, Management

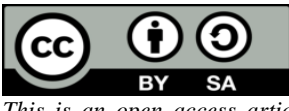

This is an open access article under the CC BY-SA license.

Copyright (C) 2021 by Author. Published by Universitas Pendidikan Ganesha

\begin{abstract}
A B S T R A K
Pengelolaan sarana dan prasarana menjadi penting dalam pendidikan jasmani, mengingat sarana dan prasarana merupakan sarana penunjang keberhasilan pembelajaran. Penelitian ini bertujuan untuk mengetahui bagaimana pengelolaan sarana dan prasarana pendidikan jasmani di SMP Negeri. Penelitian ini merupakan jenis penelitian kualitatif dengan desain penelitian studi kasus. Data diperoleh melalui wawancara, observasi, dan dokumentasi. Data penelitian diperoleh dari enam sumber yang terdiri dari kepala sekolah, guru pendidikan jasmani, dan staf sarana dan prasarana. Analisis data menggunakan analisis Miles dan Huberman. Hasil penelitian tentang ketersediaan dan pengelolaan sarana dan prasarana mengungkapkan bahwa ada beberapa sarana dan prasarana pendidikan jasmani yang layak tetapi memiliki ketersediaan. Kegiatan pemindahan sarana dan prasarana pendidikan jasmani yang belum terlaksana dengan baik mengakibatkan banyak sarana dan prasarana yang rusak menumpuk di gudang. Proses inventarisasi telah dilakukan dengan baik. Hal ini terlihat dari proses pendaftaran barang atau sarana dan prasarana yang dicatat secara alfabetis dengan nama-nama barang yang telah dibelanjakan, proses inventarisasi dilakukan secara rutin dan teratur. Proses pemeliharaan sarana dan prasarana pendidikan jasmani dilakukan oleh guru dan siswa.
\end{abstract}

\section{A B S T R A C T}

Management of infrastructure and facilities is important in physical education, considering that infrastructure is a medium to support the success of learning. This study aims to determine how the management of physical education facilities and infrastructure in State Junior High Schools. This research is a type of qualitative research using a case study research design. Data obtained through interviews, observation, and documentation. The research data were obtained from six sources consisting of the principal, physical education teachers, and facilities and infrastructure staff. Data analysis used Miles and Huberman analysis. The results of research on the availability and management of facilities and infrastructure revealed that there were several physical education facilities and infrastructure that were feasible but had their availability. The removal of physical education facilities and infrastructure activities that have not been carried out properly has resulted in many damaged facilities and infrastructure piled up in the warehouse. The inventory process has been carried out well. This can be seen from the process of registering goods or facilities and infrastructure which are recorded alphabetically by the names of items that have been spent, the inventory process is carried out routinely and regularly. The process of maintaining physical education facilities and infrastructure is carried out by teachers and students.

\section{INTRODUCTION}

Physical education is one of the subjects that have been applied to the curriculum of Elementary Schools (SD), Junior High Schools (SMP), and Senior High Schools (SMA). Physical education is learning which involves movement and physical activities to maintain and improve student fitness (Dewi et al., 2021; Leonard, 2014). Physical education is part of overall education that prioritizes physical activity and fostering a healthy life for physical, mental, social, and emotional growth and development that is harmonious, harmonious, and balanced. Good physical education learning includes aspects consisting of sports activities, the existence of curriculum, assessment, and teaching as well as other supporting factors such as infrastructure, professional teachers and others (Harimurti, 2018). Through the physical education learning level in schools, students will be provided with basic abilities and skills to be able to move actively and keep the body in shape (Harsuki, 2012). The success of physical education learning is directly related to how the infrastructure supports it. This is clearly stated in the Regulation of the Minister of National Education of the Republic of Indonesia Number 24 of 2007 concerning the standard of facilities and infrastructure for SMP / MTs. In line with the above statement, stated in the National Education System Law Number 20 of 2003 Chapter VII Article 42 Paragraph 1 and 2 states that every 
education unit is obliged to have the facilities and infrastructure needed to support the learning process. Educational facilities and infrastructure are a component that is needed and important in supporting the education process so that it is fulfilled properly (Rosivia, 2014). Physical education facilities are very helpful tools in the teaching and learning process of Physical Education (Arman, 2014). Physical education learning requires adequate facilities in teaching and learning activities if existing facilities are met so that plans or learning objectives can be maximally achieved (Rainer et al., 2014).

Talking about the facilities and infrastructure needed in Physical Education learning, good management is needed. This is because to improve the quality of physical education facilities and infrastructure that are good and by the standards set by the government. In line with this opinion, the management of the infrastructure carried out is to regulate and supervise how the maintenance and operation of the facilities are well (Schwarz, 2010). The evaluation function, the administration of organizing in schools are very important so that the existing facilities and infrastructure at school will always be in a condition that is ready to be used (Ajibua, 2016). Evaluating the facilities and infrastructure of physical education has very important functions such as planning, organizing, monitoring, and leadership functions (Vincent, 2013). In the evaluation of facility management the need for good cooperation to manage, be responsible and coordinate all efforts on starting planning, designing, and procuring existing facilities (Amaratunga \& Baldry, 2015). Based on the explanation above regarding physical education learning that will succeed with the support of existing facilities and infrastructure and there should be management maintenance, it is something that needs to be paid attention to. The management that is carried out involves physical education teachers, school principals, and staff who are specifically tasked with paying attention to existing facilities and infrastructure. With the good management of Physical Education facilities and infrastructure, it will contribute to the learning objectives of Physical Education and sports achievement, as well as the conditions of Physical Education facilities and infrastructure will always be organized, maintained, and always in a ready to use condition. Based on the results of the explanation regarding the importance of managing facilities and infrastructure, this research will focus on the management of facilities and infrastructure at SMP Bengkulu Utara. This is done considering that until now there are no research results that reveal how management is carried out on existing facilities and infrastructure.

\section{METHODS}

In this study, researchers used a qualitative research type using a case study research design (case study). A case study is a method or design used to collect and analyze data relating to a case (Sukmadinata, 2012). The subjects in the study were informants who knew, were responsible, and were directly involved in the planning process until the availability of physical education facilities and infrastructure in public junior high schools 02 and 04, Argamakmur District, North Bengkulu Regency. This research uses data collection instrument from an interview, observation, and documentation. Qualitative data analysis was carried out interactively and continued to completion. The data analysis used by researchers is data analysis by Miles Huberman's model which includes data reduction, data display, conclusion doing, and verification (Milles \& Huberman, 1992; Sugiyono, 2017). The interactive model data analysis steps can be described by Figure 1.

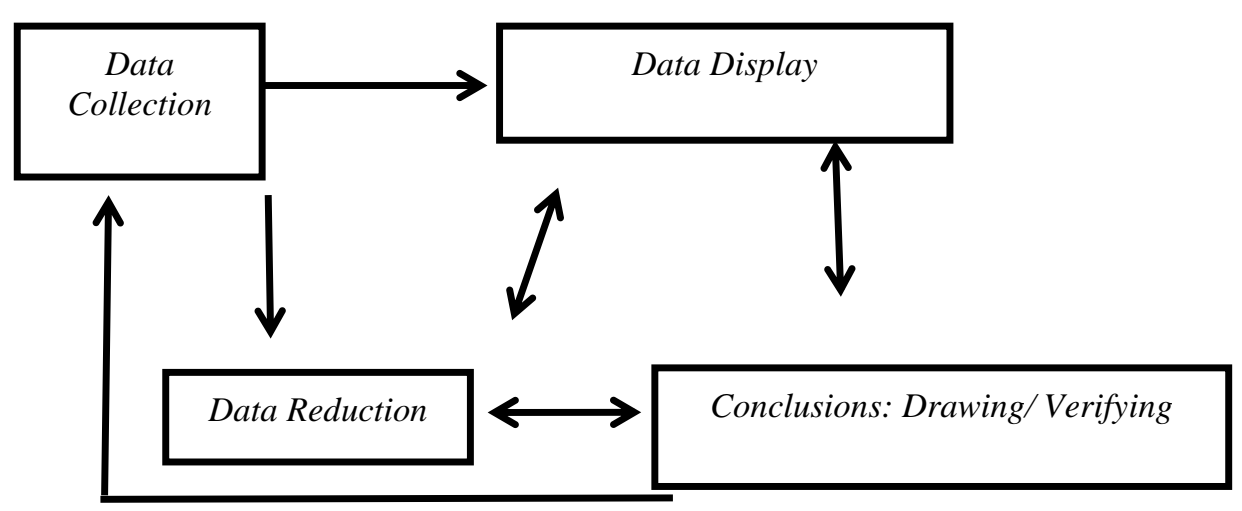

Figure 1. Data Analysis of Miles and Huberman Sugiyono's Model 


\section{RESULT AND DISCUSSION}

\section{Results}

The results of research on the availability and management of facilities and infrastructure reveal that there are several physical education facilities and infrastructure that are limited in number and also do not meet the standards set by the government. This can be seen when researchers research that the facilities and infrastructure used during the learning process only use one ball and there are still facilities such as a flat or leaking basketball and volleyball so that they cannot be used to support the physical education learning process because the number is only one so that there is no spare ball for use in learning. The removal of physical education facilities and infrastructure activities that have not been carried out properly has resulted in many damaged facilities and infrastructure piled up in the warehouse. The inventory process has been carried out well. This can be seen from the process of registering goods or facilities and infrastructure which are recorded alphabetically by the names of goods that have been spent, the inventory process is carried out regularly and regularly. The process of maintaining physical education facilities and infrastructure is carried out by teachers and students. This was seen by researchers when conducting research where the maintenance process was carried out by teachers and students when the Physical Education learning process ended and this maintenance was carried out before the Physical Education facilities and infrastructure were stored in an available storage area. Furthermore, the table below will reveal each of the results of each school, that is, what is done in two junior high schools in Bengkulu will be shown in the table below, the table below will reveal the infrastructure available at each school that supports successful learning Physical Education from each school that has been researched. Table 1 discuss the existing infrastructure at SMPN 02 Bengkulu Utara.

Table1. Facilities and Infrastructure for Physical Education at SMPN 02 BU

\begin{tabular}{lllll}
\hline \multirow{2}{*}{ No. } & \multicolumn{2}{l}{ Physical Education Infrastructure. } & Physical Education Facilities & \\
\cline { 2 - 4 } & Type of Infrastructure & Sum & Type of means & Sum \\
\hline 1. & Field & 1 & Basketball & 6 \\
2. & Tub Long Jump & 1 & Bullet & 2 \\
3. & Futsal field & 1 & Volleyball & 1 \\
4. & & Futsal ball & 2 \\
5. & & Futsal goal & 2 \\
6. & & Foot-ball & 1 \\
7. & & Cones & 20 \\
8. & & Gymnastic Mat & 1 \\
9 & & Volleyball Net & 1 \\
10. & & Badminton net & 1 \\
11. & & Takraw ball & 1 \\
\hline
\end{tabular}

Based on Table 1, it is revealed that the infrastructure owned by the school is in a good category or sufficient to support the success of physical education learning. For the completeness of the infrastructure that is owned, it is quite well proven by the existence of a field the size of a football field that can be used for a ceremonial field, then the existence of a futsal field that is different from a soccer ball field, the existence of a long jump. Then for the completeness of the ingredients that are owned is quite good, there are six basketballs, two bullets, saty volleyball, two futsal balls, two futsal goals, one football, twenty lines, one gym mat, one net volley, one net. badminton, one piety ball. Based on this explanation, the facilities and infrastructure owned are good enough to support the success of learning. Even though it is quite good, the researcher suggests to be able to add sports facilities that only have one number, this is because if there is damage to the facility it can have reserves so that it does not interfere with learning due to the lack or not and the difficulty of the facilities that must be used for learning media. It is revealed that the infrastructure owned is less than that of SMP 02 Bengkulu Utara, this can be seen if the school has a soccer field used for ceremonies, as well as a sandbox for long jumps. What distinguishes SMP 02 North Bengal is the absence of a futsal field. Then the table above also reveals if the facilities owned are quite complete, namely, there are three basketball balls, four bullets for making, one volleyball, and two futsal balls and two futsal goals. There is no special ball used for football which is different from the futsal ball, there are twelve cones, one gym mat, one net volleyball, one net badminton, no takraw ball, there are six sticks used for runners. relay, one ping pong table, one net ping pong and there are six ping pong beds. From the results of the research it was revealed that the facilities owned were more complete when compared to the previous school, even so, the infrastructure owned was not better than the 
previous school. For facilities that only have one fruit, it is hoped that they can be added to support success, it is hoped that there will be a backup in case something untoward happens to the suggestions to be used. Facilities and infrastructure are important components in physical education learning, this is expressed because as a physical education learning medium in exploring physical activities and movements that are carried out during learning, infrastructure management.

\section{Discussion}

Management plus facilities and infrastructure play an important role in supporting development (Hanggara et al., 2019; Pahlevi et al., 2016). The process of planning and procuring physical education facilities and infrastructure can be done by first registering what facilities and infrastructure are needed for the learning process. This data collection function is to identify good facilities and infrastructure that cannot be used anymore. The educational facilities and infrastructure in schools are a dimension and a reflection that the school has a quality education (Dewi et al., 2021; Nylon, 2013). Furthermore, this can be done by holding a physical education facility and infrastructure planning meeting by the school. This is also in line with the opinion which states that planning the necessary facilities and infrastructure needs, among others, by determining in advance the need for facilities and infrastructure that are per the curriculum used by taking into account the number of students available and selecting the tools to be spent. and tools that teachers can develop themselves (Depdiknas, 2001; Irawan \& Prasetyo, 2019). Conduct procurement must be in unde priorities and record orderly and regularly and include it in the RAPBS.

The results of the research conducted by researchers regarding the management of physical education facilities and infrastructure in schools, from the results of the research that has been carried out, there are still some facilities and infrastructure that are not feasible and do not comply with the standards set by the government. The importance of good physical education facilities and infrastructure will greatly help in improving the quality of learning that will be carried out in schools. The need for goods is an activity in planning items that can support the learning process so that it can achieve the objectives of the learning (Jabar, 2016; Rohmah et al., 2020). The availability of educational facilities and infrastructure in schools that are following standards affects the success of the learning objectives to be taught (Marmoah \& Denmar, 2017). Many components of adequate school facilities and infrastructure are important in creating a productive learning and teaching environment for students and teachers (Handoko et al., 2020; Ibrahim et al., 2016).

When proposing facilities and infrastructure, usually the school takes notes and measures. This is in line with the opinion that determining the ideal number of physical education facilities and infrastructure that should be owned by each school, which can be measured by looking at the standards of using existing facilities and infrastructure (Herman \& Riady, 2018; Kroupis et al., 2019). Both SMPN 02 and SMPN 04 BU have made proposals for facilities and infrastructure, but because these two schools rely on BOS funds, it is necessary to determine the priority scale. This is under what was conveyed that in planning and procuring facilities and infrastructure it is necessary to accommodate all existing proposals, then make plans for the necessary equipment which will then be combined with existing equipment (Bafadal, 2014; Javanmardi \& Bagheri, 2013). This must be adjusted to the existing budget to determine and determine the final procurement plan.

After planning, the necessary facilities and infrastructure will be procured by considering existing finances or funds. SMPN 02 and 04 BU have carried out the planning and procurement of physical education facilities and infrastructure which are quite good and under the rules or procedures in planning and procuring facilities and infrastructure. This is as explained that the procedure for procuring goods and services refers to the Presidential Decree No. 80/2003 which has been refined by Permen No. 24/2007 (Matin \& Fuad, 2018). Procurement of educational tools, especially in the subject of physical education (Physical Education) can be carried out by purchasing facilities and infrastructure that are tailored to the needs, making the necessary facilities and infrastructure yourself. This can be carried out according to the ability and according to the available costs, receiving assistance or grants or gifts given by the government, private, or individual institutions for schools.

SMPN 02 and 04 Bengkulu Utara have established schools that are orderly and orderly with administration so that later the physical education facilities and infrastructure that have been purchased using BOS funds can be held accountable if there is an examination by the financial audit agency (BPK). In line with the statement above, it was also explained that an inventory of goods compiled by an organization that is complete regularly and sustainably can provide benefits in providing data, providing information that can be used as a guideline when procuring goods, provide information about the condition of an item that can still be used or an item that has been damaged (Hanggara et al., 2019; Jabar, 2016). This is useful as a basis for determining the process of deleting goods, as well as providing 
information and data to make it easier to control and supervise said facilities and infrastructure. The purpose of this physical education facility and infrastructure inventory is to familiarize the school with orderly administration and make it easier for schools to carry out surveillance, to know incoming and outgoing goods as well as damaged goods and items that are still fit for use in the learning process. The educational inventory activity is an activity to register or record items that are owned by the institution (school) into an orderly and orderly list of goods inventory based on the existing provisions and procedures (Handoko et al., 2020; Matin \& Fuad, 2018). A good inventory can help students improve the quality of learning in schools so that it becomes better, this is in line with the opinion which states that an inventory of goods compiled by an organization that is complete regularly and sustainably can provide benefits in providing data, provides information that can be used as a guideline when procuring goods, provides information about the state of an item that can still be used or goods that have been damaged, this is useful as a basis for determining the process for deleting goods, as well as providing information and data to make it easier to do control and supervision of the said facilities and infrastructure (Jabar, 2016).

The use of scheduled physical education facilities and infrastructure like this allows the physical education facilities and infrastructure at SMPN 02 and 04 North Bengkulu to be maintained in good condition so that they are always ready when they want to be used for the learning process and the existing facilities and infrastructure are not lost or damaged. This is the same as stated that in the use of equipment or facilities and infrastructure, two things must be considered, namely effective and efficient (Jabar, 2016). Effective, which means all the use of educational facilities and infrastructure at the school or institution is used solely to facilitate the process of teaching and learning activities directly and indirectly. The process of maintaining physical education facilities and infrastructure is carried out by teachers and students. This was seen by researchers when conducting research where the maintenance process was carried out by teachers and students when the Physical Education learning process ended and this maintenance was carried out before the Physical Education facilities and infrastructure were stored in an available storage area. This is the same as previous study that stated that in the maintenance process there are several actions such as maintaining, protecting, continuing, supporting, protecting in good condition (Leonard, 2014).

The same thing was conveyed that the purpose of maintaining facilities and infrastructure is to optimize the life of the equipment, to ensure the operational readiness of the equipment so that it can support the smooth running of work, ensuring the availability of the necessary equipment through regular and regular checks (Javanmardi \& Bagheri, 2013; Matin \& Fuad, 2018). In principle, maintenance activities are carried out so that every facility and infrastructure is always ready to use in teaching and learning activities according to their needs. Maintenance of facilities and infrastructure, namely good maintenance resulting in rarely significant damage, if the equipment is well maintained, the age of these facilities and infrastructure will be durable and with good maintenance, the existing facilities and infrastructure will be controlled to avoid the loss (Gunawan \& Ary, 2010). The activities to eliminate physical education facilities and infrastructure carried out in schools have not yet gone well, resulting in a buildup in the storage warehouse. This is like the opinion that the deletion of goods is an activity of removing state-owned goods from the inventory list based on applicable laws and regulations (Jabar, 2016). The elimination of facilities and infrastructure actually aims to create a better learning environment. However, in carrying out deletions, several things must be considered. This is as stated that in carrying out activities to remove facilities and infrastructure, we must pay attention to, among other things: the facilities and infrastructure are in a state that is not feasible or severely damaged so that they cannot be used and repaired again facilities and infrastructure. infrastructure is not by today's needs, facilities and infrastructure are stolen, burned, or destroyed as a result of natural disasters (Matin \& Fuad, 2018). Under the opinion that the process of eliminating or removing educational facilities and infrastructure from the inventory list was carried out because the facilities and infrastructure were deemed not functioning as expected, especially for the benefit of implementing learning in schools (Matin \& Fuad, 2018).

This is in line with the opinion that the elimination was carried out to repair facilities and infrastructure that were no longer suitable for use (Darmastuti \& Karwanto, 2014). If there are inadequate facilities and infrastructure, it is necessary to remove these facilities and infrastructure. The elimination of physical education facilities and infrastructure at SMPN 02 and 04 North Bengkulu aims to eliminate physical education facilities and infrastructure that can no longer be used in the learning process, reduce the availability of unusable facilities and infrastructure in storage warehouses and reduce the workload of officers' inventory. If there are inadequate facilities and infrastructure, it is necessary to remove these facilities and infrastructure. The elimination of physical education facilities and infrastructure at SMPN 02 and 04 North Bengkulu aims to eliminate physical education facilities and infrastructure that can no 
longer be used in the learning process, reduce the availability of unusable facilities and infrastructure in storage warehouses and reduce the workload of officers' inventory.

SMPN 02 and 04 North Bengkulu also always evaluate the availability of physical education facilities and infrastructure owned by the school by conducting to sports teachers by doing this, making it easier for the principal to find out what the physical education facilities and infrastructure are needed for the teaching and learning process. before the meeting at the beginning of the semester. The synergy between teachers and school principals like this can create a school environment and the teaching and learning process can run well and is supported by adequate physical education facilities and infrastructure. Doing this also makes it easier for the school to know that physical education facilities and infrastructure are still feasible and not suitable for use in physical education learning, making it easier for the school to carry out elimination. This is as stated that in carrying out activities to remove facilities and infrastructure must pay attention to, among other things: the facilities and infrastructure are in a state that is no longer feasible or severely damaged so that they cannot be used and repaired again facilities and infrastructure. infrastructure is not following the needs of the present, facilities and infrastructure are stolen, burned, or destroyed as a result of natural disasters (Matin \& Fuad, 2018).

\section{CONCLUSION}

Based on the results of the research that has been done, it can be concluded that the availability and infrastructure have been fulfilled but it still has shortcomings for some facilities that should be more than one. For field availability, it is already available well, although there are still some aspects that do not meet the standards, in the selection conducted by teachers, staff, school principals, and students, it has been done well. The removal of physical education facilities and infrastructure activities that have not been carried out properly has resulted in many damaged facilities and infrastructure piled up in the warehouse. Even though the management is carried out quite well, the researcher suggests that it is possible to add sports facilities which only have one number, this is because if there is damage to the facility it can have a backup so that it does not interfere with learning due to the lack or not and the difficulty of the facilities that must be used for the media. learning. The results of this study are expected to be able to become a guideline for evaluating the implementation of physical education facilities and infrastructure management so that with this it is expected that existing facilities and infrastructure are by the minimum standards of physical education facilities and infrastructure that have been set and for related schools or other junior high schools can be used as reference material in carrying out the process of management activities for more effective and efficient facilities and infrastructure, starting from a series of process planning activities to the elimination of facilities and infrastructure by carrying out these activities in a structured and systematic manner, the availability of physical education facilities and infrastructure at school can be fulfilled

\section{REFERENCES}

Ajibua, A. (2016). Administration of Physical Education and Sports in Nigeria. Canadian Center of Science and Education, 2(1), 88-96. https://doi.org/10.5539/hes.v2n1p88.

Amaratunga, D., \& Baldry, D. (2015). Assessment of facilities management performance in higher education properties. Management of Facilities, 18(7/8), 293-301. https://doi.org/10.1108/02632770010340681.

Arman, A. (2014). Survei Sarana Prasarana Olahraga Dengan Efektivitas Pembelajaran Penjasorkes Smp Negeri Kecamatan Dampal Selatan Kabupaten Tolitoli. Tadulako Journal Sport Sciences And Physical Education, 2(8). http://jurnal.untad.ac.id/jurnal/index.php/PJKR/article/view/3483.

Bafadal, I. (2014). Manajemen Perlengkapan Sekolah Teori Dan Aplikasinya. PT. Bumi Aksara.

Darmastuti, H., \& Karwanto. (2014). Manajemen Sarana Dan Prasarana Dalam Upaya Peningkatan Kualitas Pembelajaran Pada Jurusan Teknik Komputer Dan Informatika Di SMK Negeri 2 Surabaya. Jurnal Inspirasi Manajemen Pendidikan, 3(3), 9-20. https://ejournal.unesa.ac.id/index.php/inspirasimanajemen-pendidikan/article/view/6606.

Depdiknas. (2001). Buku I Manajemen Peningkatan Mutu Pendidikan berbasis sekolah. Depdiknas.

Dewi, C., Windoro, D., \& Pura, D. N. (2021). Management of Physical Education Facilities and Infrastructure. Journal of Education Technology, 5(2), 291-297. https://doi.org/10.23887/jet.v5i2.34450.

Gunawan, \& Ary, H. (2010). Administrasi Sekolah. Cipta Rineka. 
Handoko, H., Rustiadi, T., \& Mukaromah, S. B. (2020). Implementation of the Use of School Operational Assistance (BOS) Funds in Fulfilling Middle School Sports Infrastructure Facilities in Ngadirejo District. Journal of Physical Education and Sports, 9(2), 108-113. https://journal.unnes.ac.id/sju/index.php/jpes/article/view/38812.

Hanggara, A. S. D., Soegiyanto, S., \& Sulaiman, S. (2019). Learning Infrastructure Facilities for Physical Education, Sports and Health Public Elementary Schools. Journal of Physical Education and Sports, 8(1), 26-32. https://journal.unnes.ac.id/sju/index.php/jpes/article/view/26295.

Harimurti, R. S. (2018). Peningkatan keyakinan diri dan hasil belajar guling depan melalui latihan imagery Improve self-efficacy and learning outcomes of the forward roll through the exercise imagery. Jurnal Keolahragaan, 6(1), 87-99. https://doi.org/10.21831/jk.v6i1.10097.

Harsuki. (2012). Pengantar Manajemen Olahraga. PT. Raja Grafindo Persada.

Herman, H., \& Riady, A. (2018). Survey Sarana Dan Prasarana Pendidikan Jasmani Di SMP/ MTS Swasta Kabupaten Pangkep. SPORTIVE: Journal of Physical Education, Sport and Recreation, 1(2), 27-35. https://doi.org/10.26858/sportive.v1i2.5624.

Ibrahim, N. M., Osman, M. M., Bachok, S., \& Mohamed, M. Z. (2016). Assessment on the condition of school facilities: case study of the selected public schools in Gombak District. Procedia - Social and Behavioral Sciences, 222, 228-234. https://doi.org/10.1016/j.sbspro.2016.05.151.

Irawan, F. A., \& Prasetyo, F. E. (2019). Sport Infrastructure for Physical Education in Senior High School. International Journal of Multicultural and Multireligious Understanding, 6(1), 66-70. https://doi.org/10.18415/ijmmu.v6i1.491.

Jabar, C. F. A. (2016). Manajemen pendidikan. UNY Press.

Javanmardi, B., \& Bagheri, H. (2013). Comparative study of indoor sport facilities and equipments of general administration of physical education and education ministry with standards in terms of safety and hygiene in Hamedan province. Research in Sport Management and Motor Behavior, 3(5), 113-124. https://jrsm.khu.ac.ir/browse.php?a_code=A-10-3-71\&slc_lang=en\&sid=1.

Kroupis, I., Kouli, O., \& Kourtessis, T. (2019). Physical Education Teacher's Job Satisfaction and Burnout Levels in Relation to School's Sport Facilities. International Journal of Instruction, 12(4), 579-592. https: //eric.ed.gov/?id=EJ1230085.

Leonard, A. (2014). Principles and practice of the maintenance of physical education curriculum facilities and equipment in schools. The International Journal Of Engineering And Science, 3(12), 23191813.

Marmoah, S., \& Denmar, D. (2017). The Analysis Of Classroom Management In Teaching English. 22(1), 7278. https://doi.org/10.9790/0837-2201037278.

Matin, \& Fuad, N. (2018). Manajemen Sarana dan Prasarana Pendidikan: Konsep dan Aplikasinya. PT RajaGrafindo Persada.

Milles, M. B., \& Huberman, A. M. (1992). Analisis Data Kualitatif (T. R. Rohidi \& Mulyarto (eds.)). Universitas Indonesia Press.

Nylon, M. R. (2013). Management of school infrastructure in the context of a no-fee schools policy in rural south african schools: lessons from the field. IJEP, 8(5), 1-13. https://doi.org/10.22230/ijepl.2013v8n5a425.

Pahlevi, R., Imron, A., \& Kusumaningrum, D. E. (2016). Manajemen Sarana Dan Prasarana Untuk Meningkatkan Mutu Pembelajaran. Jurnal Manajemen Pendidikan, 25(1), 88-94. http://ap.fip.um.ac.id/wp-content/uploads/2015/05/12-Reza-Pahlevi.pdf.

Rainer, P., Cropley, B., Jarvis, S., \& Griffiths, R. (2014). From policy to practice: The challenges of providing high quality physical education and school sport faced by head teachers within primary schools https://doi.org/10.1080/17408989.2011.603125. Physical Education and Sport Pedagogy, 17(4), 429-446. https://doi.org/10.1080/17408989.2011.603125.

Rohmah, L. N., Lufthansa, L., \& Mustofa, H. (2020). Survey Of Management Facilities And Infrastructure Of Physical Education In Special Needs School In Malang City. Jp. Jok (Jurnal Pendidikan Jasmani, Olahraga Dan Kesehatan), 3(2), 141-155. https://doi.org/10.33503/jp.jok.v3i2.625.

Rosivia. (2014). Peningkatan pengelolaan sarana prasarana pendidikan di SMP Negeri 10 padang. Journal Administrasi Pendidikan, 2, 661-668. http://repository.unp.ac.id/id/eprint/12246.

Schwarz, E. (2010). The reciprocal and influential connection between sport marketing and management and the sport sciences. Sport Management and Marketing, 7(1-2), 33-43. https://doi.org/10.1504/IJSMM.2010.02971.

Sugiyono. (2017). Metode Penelitian Kuantitatif, Kualitatif, dan R \& D. CV Alfabeta.

Sukmadinata, N. S. (2012). Metode Penelitian Pendidikan. PT. Remaja Rosdakarya.

Vincent, D. A. (2013). Manajemen Dalam Konteks Indonesia. Kanisius. 